\title{
Taxation Aspect of E-Commerce Transactions in an Online Marketplace in Indonesia
}

\author{
Fitria Arianty ${ }^{1 *}$, Hadining Kusumastuti ${ }^{2}$ \\ ${ }^{1,2}$ Tax Administration Laboratorium \\ Vocational Education Program Universitas Indonesia
}

*Email: fitria arianty_fitria@yahoo.com

\begin{abstract}
With its many advantages over conventional commerce, e-commerce as a new form of business is rapidly growing. This study discusses tax aspects of ecommerce transactions on an online marketplace in Indonesia, including corporate income taxation, withholding, and value- added taxation. After reviewing Indonesian tax regulations governing e-commerce, we employ descriptive analysis of data collected from documentation studies and prior literature. We show that Indonesia's tax treatment of e-commerce and conventional business recognizes no conceptual differences between e-commerce and brick-and-mortar commerce. In honoring five key principles governing taxation, Indonesia acknowledges that the only difference rests in use of the Internet as a transaction medium and commercial infrastructure. Therefore, all taxation rights and obligations relevant to conventional business are attached to ecommerce in Indonesia.
\end{abstract}

Keywords: e-commerce, marketplace, tax treatment

\section{Introduction}

After a decade of astounding growth the Internet is attracting millions of consumers, and billions of their dollars to its gigantic, ever-expanding virtual shopping mall (Olcay, 2011).

Electronic commerce is the computer-facilitated exchange of millions of goods or services (Office of Tax Policy, U.S. Treasury Department, 1996). Besides online trading of goods and services, e-commerce spans electronic funds transfers, online trading of financial instruments, and data exchanges between companies (Doernberg \& Hinnekens, 1999).

E-Commerce has revolutionized the conduct of business worldwide. Neither the physical presence nor physical delivery of goods and services is necessary. Its technology transforms the creation and marketing of goods and services, business processes, organizational structures, and functional areas. As a subset of ebusiness, e-commerce challenges global tax regimes. Its model differs from regular trading, wherein electronic commerce there is no physical form of store, outlet, showroom, and so on. However, this electronic trading model cannot be separated from taxation. Taxation aspects related to this electronic transaction are Corporate Income Tax or Personal Person, Withholding Tax, and Value Added Tax. The imposition of tax on e-commerce transactions should take into consideration the principles of taxation such as Neutrality, Efficiency, Certainty and Simplicity, Effectiveness, Fairness, and Flexibility.

\section{Literature Review}

Digitalization is the most important economic development since the Industrial Revolution and a driver of growth and innovation, ${ }^{1}$ but the digital economy challenges the international tax system. ${ }^{2}$ E-commerce lets businesses operate without a "permanent establishment" within national tax jurisdictions. E-commerce can involve parties in multiple countries, potentially rendering income from transactions taxable in multiple jurisdictions. The global nature of e-commerce muddles jurisdiction as a tenet of taxation and challenges traditional tax rules because businesses can exist almost entirely in cyberspace using communication tools/technology to interact with customers, suppliers, directors, and shareholders. E-commerce challenges when, where, and how taxation can be applied as local markets become global (Agrawal, K. \& Agrawal, N., 2014).

Traditional tax laws may govern new ways of conducting business, but current international tax law may not have kept pace with new global practices (Olbert \& Spengel, 2016). Some governments impose sales or VAT taxes on e-commerce transactions. The European Union imposes VAT on downloadable products sent to businesses or end users. India and the Philippines are considering e-commerce tax policies. India is a giant candidate for information technology (IT) and services exported through e-commerce. Most such products and 
services have not been taxed, sacrificing revenue to the state. If that persists, nations can lose significant income (Pangesti, 2017)

Governments will not and cannot remain oblivious to tax revenues from e-commerce even though opponents argue that acquiring and using electronic equipment are already taxed, that accessing the Internet is taxed, that swelling numbers of online businesses and employees generate taxable income, that taxation may erode competitiveness of domestic firms and benefit overseas competitors, and that taxing e-commerce might throttle fledgling businesses (Olcay, 2011). E-commerce can and will be taxed. For business-to-business sellers the die is cast: they will be collecting and remitting sales taxes for non-exempt customers.

The first important question is how to make that inevitability less painful. The pain comes in two varieties: liability for back taxes that may be due in many jurisdictions and operational complexity. Collecting and remitting sales taxes may be inevitable, but it needn't be a burden. By installing proper processes and proffering amnesty programs, sellers can assure they operate healthy, compliant businesses and focus on providing the right products (Peterson, 2017).

The second important question is how to tax it fairly and efficiently alongside conventional commerce. ABI agrees that tackling BEPS issues associated with the digital industry requires new international rules to assure cross-border digitalized businesses pay taxes owed. Achieving that goal requires a long-term strategy that permits more rigorous and comprehensive analysis of options, consideration of all effects, and a proper impact assessment (OECD, 2017). States will either continue to push for the ability to tax remote sellers, mandate that non-collecting remote vendors report buyers' purchases, encourage e-merchants to collect and remit sales taxes voluntarily, or start asking third-party merchants who use other sellers' online platforms to pay sales taxes. Some initiatives will succeed, and others will preoccupy state courts (Beebe, 2017). These are uncertain times for e-commerce generally and marketplace sellers in particular. Although consumers may be unable to imagine life without the convenience of online sellers, e-commerce is a relatively new phenomenon in the realm of taxation. States struggle to determine the best way to gather tax revenue from online sales, but they crave that revenue and will figure out how to get it. For online sellers, the best course is to plan for growth and choose a tax solution that handles any eventuality (Cole, 2017).

Policies framed by the Committee on Fiscal Affairs of the Organization for Economic Cooperation and Development (OECD) highlight neutrality, efficiency, certainty and simplicity, effectiveness and fairness, and flexibility as guiding principles for taxing e-commerce transactions (Moid, 2016). Those same principles guide taxation of conventional commerce.

- Neutrality: taxation should be neutral and equitable between conventional and e-commerce to avoid double taxation or unintentional non-taxation.

- Efficiency: compliance costs to business and administrative costs for government should be minimized.

- Certainty and simplicity: tax rules should be clear and easily understood.

- Effectiveness and fairness: taxation should produce the right amount of tax at the right time and minimize potential for evasion and avoidance.

- Flexibility: tax systems should be flexible and dynamic to parallel technological and commercial developments.

CFA used the principles above to conclude that principles that guide taxation of conventional commerce should guide taxation of e-commerce (Koyango, 2001).

This paper examines Indonesia's online marketplace as a model for imposing corporate, personal taxes, withholding, and VAT on e-commerce transactions. It also analyzes the tax aspects of e-commerce transactions in Indonesia based on applicable principles.

\section{Methodology}

This study is qualitative and descriptive research. Qualitative investigation produced descriptive data (i.e., written or spoken words, not numbers) and observed behaviors to create case studies of online transactions. We collected secondary data from Indonesian tax laws, supporting documents, and studies in journals of ecommerce taxation. We collected and analyzed this literature to understand how earlier authors' interpretations illuminate and offer solutions for problems in taxing e-commerce (Circular Letter of The Directorate General of Taxation Number 62, 2013; Circular Letter of The Directorate General of Taxation Number 06, 2015).

\section{Results and Discussion}

In 2013, Indonesia's Director General of Taxes issued Circular Letter Number 62 on Affirmation of Taxation Provisions on E-Commerce Transactions. It had a twofold purpose: to seek uniform understanding of 
the tax aspects of e-commerce and to optimize tax revenue from e-commerce under the provisions of the tax legislation. An attachment to Circular Letter 62 is an overview of business processes, revenue models, and examples of applying the General Provisions and Procedures of Taxation and income tax law. It reviews four models of e-commerce: Online Marketplace, Classified Ads, Daily Deals, and Online Retail. We discuss only the online marketplace of domestic trade transactions. If there is a difference between a model picture, business process details, and terms in the Appendix of this Circular Letter with practices occurring in the business world that are constantly modified and developed, further analysis is needed by circumstances. Business process and revenue models of the online marketplace in the above e-commerce transaction as well as the application of the relevant taxation rules are described as follows.

\section{Online Marketplace Definition}

The online marketplace includes Internet shops and malls that transact goods and services. An Internet mall is a site featuring many Internet stores and is overseen by an online marketplace organizer. Online merchants (emerchants) operate Internet stores within the mall. Thus, the four parties in e-commerce are the online marketplace, online marketplace organizer, e-merchant, and buyers.

\section{Business Process of the Online Marketplace}

a) E-merchants enroll and approve the agreement set by the online marketplace organizer.

b) The online marketplace operator verifies, approves applications for registration, and issues an invoice for a monthly fixed fee.

c) E-merchants pay the monthly fixed fee to the online marketplace organizer.

d) Online marketplace organizers provide places and times for e-merchants to display and sell content (text, graphics, videos, information, goods, services) through Internet stores in Internet malls.

\section{Process of Selling Goods and Services:}

a) E-merchants sell goods and services by uploading information.

b) Online marketplace organizers verify and display information about goods and services sold.

c) Buyers orders from the Internet store, perhaps after online marketplace organizers require them to register.

d) Online marketplace providers issue transaction details and amounts to buyers (goods type, prices, quantities, payment methods, delivery mechanisms, related charges).

e) Buyers pay through escrow accounts established by online marketplace organizers.

f) Online marketplace organizers notify e-merchants to deliver purchases to buyers.

g) E-merchants deliver purchases using their facilities or shipping services. E-merchants notify the online marketplace organizer to inform customers they have shipped their goods and services.

\section{Delivering Sales to e-Merchants by Online Marketplace Organizers}

a) Online marketplace organizers deposit sales proceeds through accounts established by the e-merchant

b) Amounts deposited are the transaction value minus sales fees, points, and other charges.

c) The period of deposit sales proceeds by online marketplace provider to e-merchant is specified by legal agreement.

\section{Tax Aspects of the Online Marketplace}

\section{A. Tax Aspects of Provisioning Services}

\section{Income Tax}

Tax Objects: Income from providing space and time in other media for delivering information is taxable and subject to withholding under Articles 23, 21, or 26 of Indonesian income tax law. Other media include Internet sites used to operate stores, display the previously described content, and make sales. Income from this activity may include monthly fixed fees, rent, registration fees, fixed fees, or subscription fees.

For the online marketplace: For providers whose income is immune from final tax, the tax rate in Article 17 is applied to taxable income (gross sales minus costs of generating, collecting, and maintaining it) as well as for an individual taxpayer minus non-taxable income. 
Withholding income tax: E-merchants who are individual taxpayers or entities required to withhold income tax must comply with Articles 23, 21 or 26. The rate specified by Article 23 on income from providing space and time in other media to deliver information is $2 \%$ of the gross amount excluding VAT. If the merchant has no taxpayer identification number, the rate is $4 \%$ excluding VAT. Rates specified in Article 26 are $20 \%$ of the gross amount excluding VAT or applicable tax treaty.

\section{Value-Added Tax}

Tax Objects: Delivering information on other media is a taxable service (JKP). Other media include Internet sites used to operate a store, display content as previously described, and making sales. Income from this activity may be monthly fixed fees, rent, registration fees, or subscription fees. Submission of JKP within a customs area or using JKP outside the customs area within the customs area is subject to VAT. The tax bases are reimbursements, including fees requested or should be requested by the online marketplace provider because of the submission of JKP, excluding withholding and rebates included in the tax invoice. VAT owed for delivering taxable services within the customs area when 1) the fee received is recognized as receivables or income, or upon issuance of a sales invoice by a taxable person for VAT purposes, in accordance with generally accepted accounting principles and applied consistently; or 2) contract or agreement signed, or 3) At time of payment, in the event payment is received prior to delivering JKP within the customs area.

Tax: VAT due for using taxable services outside the customs area, i.e. 1) when the price of those services is expressed as debt by the beneficial owner; 2) Reimbursement of such services is billed by the party who submits it, or 3) the price of the taxable service is paid in part or full, incurred first, or on the date of signing a contract or agreement if use of taxable services outside the customs area is unknown. Tax invoices are created when VAT becomes payable.

\section{B. Tax Aspects of Selling of Goods and Services}

\section{Income Tax}

Tax Objects: Earnings from selling goods and providing services are taxable income. If the income is subject to tax withholding, it is mandatory for the deduction/collection of income tax.

Tax Rate: For e-merchants on an online marketplace whose income is not subject to final tax, the Article 17 tax rate is calculated as described earlier as well as for an individual taxpayer minus non-taxable income. Buyers who pay personal income tax or are appointed as tax withholders/collectors must withhold tax at rates and under procedures specified by applicable law.

\section{Value-added Tax}

Tax Objects: Delivery by e-merchant to buyers of taxable goods or services, which may be: 1 . delivering taxable goods or services within the customs area; and/or 2. exporting tangible or intangible taxable goods or services. The tax base for VAT is the selling price, reimbursement, or export value, including fees required or which the e-merchant should request by due to the submission of taxable good and/or taxable service (price of goods or services, shipping costs, insurance). VAT is due when payment is received by the online marketplace provider.

\section{Tax Aspects of Delivering Sales Results To E-merchants By Online Marketplace Organizers Income Tax}

Tax Objects: Earnings from the services of intermediaries are taxable income under Articles 23, 21, or 26. Payments for intermediary services on the online marketplace may be per-sale fees and other charges. For online marketplace providers whose income escapes final tax, the tax rate under Article 17 applies to gross sales minus related costs as well as for an individual taxpayer minus non-taxable income.

Withholding income tax: E-merchants who are individual taxpayers or designated an income tax withholder the user of the service must withhold under Articles 23, 21 or 26. The tax rate under Article 23 on income from delivering information via other media is $2 \%$ of the gross amount excluding VAT. If service providers lack a taxpayer identification number, the rate is $4 \%$. The tax rate under Article 26 for income from providing that service is $20 \%$ of the gross amount excluding VAT or rates applicable under treaty. 


\section{Value-added Tax}

Tax Objects: Payments for intermediary services by the online marketplace provider to e-merchants are taxable. Submission of taxable services within the customs area or commissioning of taxable services outside it are subject to VAT. The VAT tax base includes reimbursements, fees requested or that e-merchants should have requested for payments to intermediaries (per-sale fees, service provider settlement fees, credit card/debit/Internet banking fee) excluding VAT collected and the discounted price on the tax invoice.

\section{Analysis}

Taxing e-commerce transactions does not differ in principle, from taxing conventional transactions, and identical principles should apply equally to both. As described and defined earlier, those principles are neutrality, minimal compliance costs, certainty and simplicity, effectiveness and fairness, and flexibility. We now examine whether Indonesia's taxation of e-commerce honors them.

\section{Neutrality}

Regulations in the Circular Letter of the Director General of Tax No. 62 of 2013 and Number 06 of 2015 are neutral concerning taxation of e-commerce and conventional commerce. Income from e-commerce is taxable to corporations and individuals at rates imposed under Article 17 of the Income Tax Law. In both cases taxable income is calculated as gross income minus allowed expenses, with individual taxpayers enjoying an additional deduction from taxable income. Tax withheld by others on income not subject to tax may be a tax credit. Earnings from e-commerce that may be subject to withholding or tax collection by other parties include income from distributing information via other media that is subject to withholding under Articles 23, 21 , or 26. Tax deductions are taken by the e-merchant as a service user. VAT imposed on online transactions is identical to VAT imposed on conventional transactions. Goods not subject to VAT are untaxed whether transacted online or conventionally. The provision of VAT "backs" applies online sales to end consumers other than taxable entrepreneurs. VAT applies to information delivered via other channels. Indonesia honors the principle of neutrality in taxing conventional and e-commerce transactions. Tax treatment will not affect buyers' or sellers' choice between conventional or online transactions.

Efficiency The principle of efficiency requires that compliance and administrative costs of collecting taxes should not exceed tax paid or collected. Online transactions are more efficient in cost and time than conventional transactions. Fulfillment of tax obligations for online shoppers do not differ from other taxpayers. Online shoppers must report and pay tax owed under Indonesia's self-assessment system. The mechanism for reporting and depositing taxes is the same as for conventional business, whether it be manual or electronic (ebilling, e-payment, e-filling, e-spot). The reduced time and cost of e-merchants meeting tax obligations electronically is easier and more efficient.

\section{Certainty and Simplicity}

Simplicity means that regulations should be easy to understand, implement, and obey. Indonesia has not issued tax regulations specific to e-commerce. The Circular of the Director General of Taxes is the only existing regulation. That is because the government perceives no difference in tax treatment of e-businesses and conventional businesses and sees no need for separate laws to regulate taxation of e-commerce. But in 2017, Indonesia issued Presidential Regulation No. 74 as a national roadmap for electronic commerce spanning 20172019. Table 1 specifies its goals.

Table 1. Road Map of Taxation Program

\begin{tabular}{|l|l|l|}
\hline Tax Program & \multicolumn{1}{|c|}{ Activity } & \multicolumn{1}{c|}{ Output } \\
\hline $\begin{array}{l}\text { Simplification } \\
\text { of Fulfillment } \\
\text { of Tax } \\
\text { Obligations }\end{array}$ & $\begin{array}{l}\text { a. Simplify the taxation procedure for } \\
\text { based business actors } \\
\text { electronic (e-Commerce), whose turnover } \\
\text { below 4.8 billion per year }\end{array}$ & $\begin{array}{l}\text { Application of tax rules for a business } \\
\text { actor with the amount of circulation } \\
\text { business up to 4.8 billion per year, } \\
\text { applies to trading business actors } \\
\text { electronic (e-Commerce), } \\
\text { whose turnover is below 4.8 billion per } \\
\text { year }\end{array}$ \\
\hline
\end{tabular}




\begin{tabular}{|l|l|l|}
\hline & Establish tax incentives for trade investors & $\begin{array}{l}\text { Incentive schemes } \\
\text { for venture capital firms } \\
\text { who invested in } \\
\text { Company business partner } \\
\text { that meet certain criteria, } \\
\text { including e-commerce companies }\end{array}$ \\
\cline { 2 - 4 } & $\begin{array}{l}\text { Document of grant analysis } \\
\text { tax incentives for angel investors and } \\
\text { other funding sources which fund start- } \\
\text { up businesses (start-up) in the early } \\
\text { stages }\end{array}$ \\
\hline $\begin{array}{l}\text { Preparation of } \\
\text { Registration } \\
\text { Procedures for } \\
\text { e-commerce } \\
\text { business actor }\end{array}$ & $\begin{array}{l}\text { Establish regulation of obligations of business } \\
\text { actors e-commerce to enroll including foreign } \\
\text { business actors }\end{array}$ & $\begin{array}{l}\text { Rules of the trade ministry } \\
\text { on Terms and Procedures } \\
\text { Registration and Publishing } \\
\text { Number of Identity of Business Entities } \\
\text { of Electronic Trading Transaction } \\
\text { (TPMSE) }\end{array}$ \\
\hline $\begin{array}{l}\text { The equation } \\
\text { of Tax } \\
\text { Treatment }\end{array}$ & $\begin{array}{l}\text { Arrange regulations that support the imposition } \\
\text { tax on foreign e-commerce business actors } \\
\text { and local according to the provisions of the } \\
\text { laws and regulations in the field of taxation }\end{array}$ & $\begin{array}{l}\text { Regulation of the Minister / Head of the } \\
\text { institution } \\
\text { related sectors }\end{array}$ \\
\hline
\end{tabular}

\section{Effectiveness and Fairness}

Absent specific laws concerning taxation of e-commerce, current tax rules preserve equal taxation of ecommerce and conventional commerce. The Directorate General of Taxation needs a complete and accurate database to monitor who receives income and to verify taxpayers' calculations, taxes, and payments as a basis for compliance and corrective action. Supervision can also be done by establishing a supervisory body to monitor Internet communication to forestall cybercrime. Implementing cyber law takes a long time because the authorities should at least form a new container and train people through training so that any form of promotion conducted on the Internet must be taxed. Finding data for taxpayers engaged in e-commerce can be easier and valid when compared with doing tax census that must go shopping or shop one by one (Pangesti, 2017). Tax provisions provide equal treatment of e-commerce and conventional business.

\section{Flexibility}

Indonesia's tax laws and mechanisms are abreast of the shift from conventional to electronic transactions. Indonesia has campaigned for and instituted electronic e-registration, e-payment, e-billing, e-spt, e-filling. Indonesian taxpayers - including e-commerce entrepreneurs - now prefer electronic media in fulfilling their tax obligations easily and more efficiently.

\section{Conclusion}

This study can be concluded as follows:

1. Indonesia does not differentiate tax treatment of e-commerce and conventional transactions. Taxation will not affect buyers' or sellers' choice of operating method.

2. Taxation of e-commerce in Indonesia has so far fulfilled the five principles of taxation: neutrality, certainty and simplicity, efficiency, effectiveness and fairness, and flexibility. However, the Indonesian government needs to improve the regulations covering existing e-commerce transactions to avoid tax evasion in cyberspace.

\section{References}

Agrawal, K., \& Agrawal, N. (2014). Impact of e-commerce on taxation. International Journal of Information and Computation Technology, 4(1), 99-106. Retrieved from http://www. irphouse.com /ijict.htm

Beebe, J. (2017). E-commerce: Recent developments in state taxation of online sales. Houston, TX: Baker Institute of Public Policy. 
Cole, G. (2017). Who should collect tax on marketplace sales? Retrieved from https://www1.avalara.com/us/en/blog/2016/12/who-should-collect-tax-on-online-marketplace-sales

Doernberg, R., \& Hinnekens, L. (1999) Electronic commerce and international taxation. Suffolk Transnational Law Review, 233, 2000-2001.

Koyango, T. O. (2001). The impact of electronic commerce on taxation, VAT aspects of e-commerce. $4^{\text {th }}$ VAT/GST Commissioners' Forum.

Moid, S. (2016). Taxing e-commerce transactions: A global perspective. SAMVAD, 11, 78-83.

OECD, (2017). Request for input on work regarding the tax challenges of the digitalised economy. Retrieved from https://www.oecd.org/tax/tax-policy/tax-challenges-digital-economy-request-for-input.pdf

Office of Tax Policy, U.S. Treasury Department (1996). Selected tax policy implications of global electronic commerce. Retrieved from https://www.treasury.gov/resource-center/tax-policy/Documents/ReportGlobal-Electronic-Commerce-1996.pdf

Olbert, M., \& Spengel, C. (2016). University of Mannheim Business School.

Olcay, H. O. (2011). E-Commerce and taxation: Understanding the difficulties. Retrieved from http://www.mfa.gov.tr/e-commerce-and-taxation_-understanding-the-difficulties.tr.mfa

Pangesti, R. D. (2017). Menguak Permasalahan Perpajakan E Commerce di Indonesia dan Solusi Pemecahannya. Jurnal Riset Akuntansi dan Bisnis Airlangga, 2(1), 181-201.

Peterson, S. (2017). How to deal with online sales tax on B2B marketplaces. Retrieved from https://www.digitalcommerce360.com/2017/09/06/deal-online-sales-tax-b2b-marketplaces/

Republic of Indonesia (2013). Circular Letter of the Director General of Tax, Number 62.

Republic of Indonesia (2015). Circular Letter of the Director General of Tax, Number 06.

Republic of Indonesia (2017). Presidential Regulation, Number 74. 